\title{
Model Of Empowerment Of Poor Women Based On Creative Economy And Local Age
}

\author{
Yosi Safri Yetmi ${ }^{1}$, Nesyah Ahdiyatuningsih ${ }^{2}$ \\ Islam Syekh Yusuf Tangerang University ${ }^{1,2}$ \\ Gang Damai No.10, Babakan, Kec. Tangerang, Kota Tangerang $15118^{1,2}$ \\ Indonesia \\ e-mail: safriyetmi@yahoo.co.id ${ }^{1}$, nesyahahdiyatu21@gmail.com ${ }^{2}$
}

(APA style, Justify, Arial 10pt) Example:

To cite this document:

Yetmi, Y. S., \& Ahdiyatuningsih, N. (2020). The Model of Empowering Poor Women Based on Creative Economy and Local Age. Aptisi Transactions On Technopreneurship (ATT), 2(1), 75-86.

DOI : https://doi.org/https://doi.org/10.34306/att.v2i1.72

\begin{abstract}
Poverty in Indonesia is still one of the social problems. Central Bureau of Statistics (BPS) noted, as of March 2017 the number of poor people, namely residents with per capita expenditure per month below the poverty line) in Indonesia reached 27.77 million people (10.64 percent of the total population). As quoted by the Head of BPS, that number increased 6.90 thousand people compared to September 2016 which amounted to 27.76 million people (10.70 percent). Although the percentage of poverty rates has decreased, in total the number has increased. Women's empowerment is an effective way to eliminate poverty, hunger, and disease and to support sustainable development. Some things must be considered in order shaping the model of empowering poor women is: the empowerment stage is preceded with the formation of empowerment models that are arranged systematically and scientifically, with combining theoretical aspects of empowerment, needs in the field, consultation with relevant agencies, literature review, as well as input from empowerment and gender experts, the existence of cooperatives was formed after the production system ran smoothly. Establishment of this cooperative need to be supported by motivating the consultant. High potential in undergoing an entrepreneurial profession or possessing high potential as a prospective entrepreneur or entrepreneur. Entrepreneurship training for Poor women in using the Project Based Learning model are considered effective because most participants are successful in terms of the level of mastery of personality (soul) entrepreneurship and skills possessed while gaining learning experience real business.
\end{abstract}

Keywords : Model of empowerment of poor women, creative economy, local wisdom

\section{Introduction}

Poverty in Indonesia is still a social problem. Poverty becomes one of the most important measures for knowing the level of welfare of a house stairs. Poverty is a problem development marked by unemployment, underdevelopment, and adversity. The dimension of poverty is not only in the economic dimension, however also involves other dimensions, like social, cultural, political, even ideological (Basuki \& Presetyo, 2007). Chambers argues that

Model Of Empowerment Of... 
the essence of the problem poverty lies in deprivation traps or deficiencies trap which includes five elements namely (1) poverty itself; (2) physical weakness; (3) alienation; (4) vulnerability, and (5) powerlessness (Soetrisno, 1995). The Central Statistics Agency (BPS) notes, in March 2017 the number of poor people, that is population with per capita expenditure per month below the Poverty Line) in Indonesia reached 27.77 million people (10.64) percent of the total population). As quoted from the Head of BPS, the figure 6.90 thousand people added compared with September 2016 conditions which amounted to 27.76 million people (10.70 percent). Even though the percentage of poverty experienced decreased, in terms of numbers the increase. For information, the percentage of population poor in urban areas in September 2016 by 7.73 percent, down to 7.72 percent in March 2017. Meanwhile, the percentage of poor people in the area villages in September 2016 amounted to 13.96 percent, down to 13.93 percent in March 2017. During the period September 2016-March 2017, the number of poor people in urban areas increased by 188.19 thousand people (from 10.49 million people in September 2016 became 10.67 million people as of March 2017). Meanwhile, in rural areas fell as many as 181.29 thousand people (out of 17.28 million people in September 2016 became 17.10 million people in March 2017). https://www.bps.go.id/Brs/view/id/1379 International commitments (2000) confirms the importance of efforts to realize equality gender and women's empowerment as a way effective for eliminating poverty, hunger, and disease as well as for support sustainable development. The application of a gender perspective in viewing poverty is not to understate meaning poverty experienced by men, but for confirms that poverty is experienced women are specific, so they are needed there is special handling too (Darwin, 2005). There are three important reasons why women must be empowered in context poverty alleviation, namely:

1. Because women have interests which is the same in development and also is a user of the results of development who have the same rights as men

2 Women also have a vested interest specifically for the woman herself and children, if less than optimal conceived by men because requires sensitivity in nature specifically, related to everyday and existing social culture

3. Empower and involve women under construction, no way directly empower women inside development and transmit the spirit positive to the next generation (Ratnawati, 2011 in Darmawan, 2012).

Empowering women in development, through creative industries based on wisdom local. Creative industries are the basis creative economic development. In recent years, the role of the creative industry in the community is quite significant. Previous research shows the influence of creative industries on activities community economy. Creative industry is one of the pillars in building National economy, as it is capable To create human resources that In the era of globalization, as well as The welfare of the community, which Make it viewed very strategically. Creative economic Developments Show A positive picture, in which this sector Grows 5.76 percent or above average National economic growth of 5.74 Percent, with added value of Rp 641.8 Trillion or 7 percent of national GDP. From The Labour side, the sector is able to absorb 11.8 million labor or 10.7 percent of The national labour force, followed by Number of business units reached 5.4 million Units or 9.7 percent of the total business unit. Meanwhile, the export activities of this industry Well, i.e. reaching Rp118 trillion or 5.7 percent of total national exports.

The government has set 15 subsectors in In the creative economy in Indonesia. Economic The intended creative among others Advertising, fashion, crafts, movies, music, Performing arts, radio and television, as well as others. Of the 15 sub sectors of economy

The creative, there are 3 sub sectors of economic Creative that contributes the greatest contribution To gross domestic product (GDP) Indonesian. Third creative economic sub sectors such as culinary, fashion, and Crafts (www.detikfinance.com, 2017). Culinary of Rp 209 trillion or $32.5 \%$, fashion of Rp 182 trillion or $28.3 \%$ and crafts amounting to Rp 93 trillion or $14.4 \%$ (in-house Kadin, MSMES, Cooperative, and creative economy, 2016). 
This study is a literature study. Based on previous exposure, this Study the model used Poor women-based empowerment Creative economy and local wisdom in Indonesian.

\section{Study Library}

\subsection{Poverty}

Poverty is an individual inability To meet basic needs at least To live Worthy (BPS and Depsos, 2002). The understanding of poverty today has Expanded, as theThe complexity of causal factors, As well as other problems Encapsulating. Poverty is not only From the economic dimension alone, It extends to the dimensions of the Social, health, education and even Political.

Poverty comes from the word poor Get prefix to and suffix an to be Poverty. In the Great language dictionary Indonesia New Edition (2012), poor meaning is not a noun, all-round Shortcomings, papa, very destitute. In English, poor as poor or can be interpreted as having a money few Possession Not having enough money for the Basic things that people need to live properly, The meaning of not having enough money For the basic things that people need to live properly (Stevenson, 2010). The above statement contains two forms Causal in interpreting the word poor, namely: (i) Poor have a very small amount of something; and (ii) poor as not Both in terms of quality and condition

Another opinion expressed by Gonner, 2007, that poverty is interpreted as " Lack of welfare " and "welfare As a lack of poverty ". Means Poverty translates as Declining welfare. Both are mutually Related issues and view the same of two different dimensions. The definitions Widespread poverty is " the lack of "Welfare, where there is a mutual exchange of This concept (Case, 2010). For example when Community is very less prosperous, meaning Poor. On the other hand, when They are in very His life is characterized by Prosperity, happiness and satisfaction (Albornoz, 2007).

Further stated by Sajogya in the Bagong Suyanto (2013:4) has made A boundary or classification of poverty as follows:

A. For urban areas, a person is called Poor when consuming less rice of 420 kilograms annually.

B. For rural areas, a person is called Poor when consuming rice 320 The kilogram, poor when Consume rice 240 kilograms and most Poor when consuming less rice of 180 kilograms annually.

The world Bank has defined poverty Global poverty measurement standards, Poverty is a matter of Deficiency with minimum income US $\$ 1$ per day (Albornoz, 2007). Since the year 1980 The concept of poverty has changed From consideration of income or consumption The simple definition of a Includes multidimensional deficiencies and Welfare. World Bank and UNDP (United Nations Development Programme) Implementing the definition of poverty Include aspects such as the need for The basic, self-determined lifestyle, Options, assets, capabilities, social inclusion, Inequality, human rights, Settlement, vulnerability, empowerment and Subjective welfare (World Bank, 2008).

According to the Central Statistic Agency (BPS), Poverty is defined as a state or lack of prosperous conditions calculated In Rp (Rupiah) per capita per month on the The other, Minimum physical needs (KFM) The benchmark of poverty definition Translated as less 
conditions due to Necessities of life (food, drink, Clothing, home) for one month Based on calorie count, proteins, vitamins and other mineral materials required to To live worthy of a worker.

http://www.edugovindonesia.com/web/index.php/2-uncategorised/25-pengertian-kemiskinan-m enurut-para-ahli.html.

Here is a poverty profile in Indonesia The poster issued by the central agency Statistics (BPS)

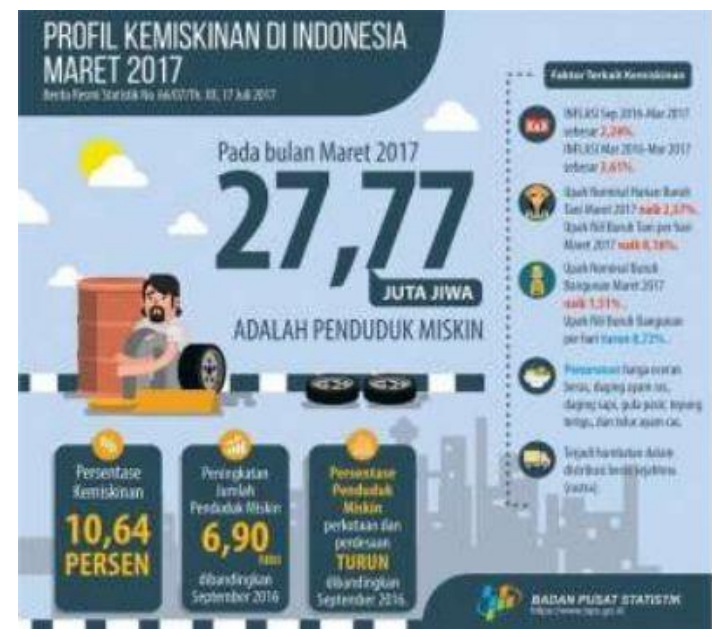

Figure 1 Poverty profile in Indonesia

2.2 Women's economic Empowerment

The term Empowerment (empowerment), According to Ginanjar Kartasasmita is an effort To build power (community) with the Encourages, motivates and raises Awareness of the potential and strive to Develop. Empowerment is A process by which people become quite Strong to participate in various control over, and affect the To the events and institutions affecting his life.

The concept of empowerment can be understood Two contexts. First, the power in Decision making process with a point and press on the importance of female roles. Second Empowerment in related terms With a focus on the relationship between Empowerment of women and consequently on Men in diverse communities. Thus the sense of empowerment is an effort to provide awareness of Potential in someone who can Power and provide benefits For himself or others, giving Motivation to grow the spirit to To activate the potential owned, and Developed through various Learning and training, so that gained knowledge and skills and Applied in concrete activities that Profitable. (Suharto, 2003)

The elements of Women empowerment are Welfare, Acces (access), Consientisation, Participation, and Equality of Control (Equality in power). While Methods of women empowerment are To dismantle racial myths, give various Skills, giving an opportunity Widest for women to progress and Improving various sectors Employment, good field of education, health, Economics, social, politics, Hankam, and culture.

\subsection{Creative Industries}

Creative industries can be defined as Following:

1. Cycle creation, production, and distribution Goods and services that use the Creativity and intellectual capital as Key input. 
2. Creative industries from a set of Activity-based knowledge that produce real goods and Intellectual non real, or services Ratindo that have creative content, economic valuators, and market visit.

3. Creative industries are composed of a field heterogeneous, affecting each other From creative activities that Varied, which are composed of art and Crafts, publications, music, visuals, and formation Art to the use of technology Intensive care and services based on the Group, film, television and broadcast Radio, as well as new media and design.

Creative industries have a role to repent National and global economies Because it contributes to Various aspects of life both inand non-economic economies. An Economy, the creative industry plays a role in Facilitating business, the creation of Employment, growing innovation and Creativity, the creators of the resources Renewable, and positively contributed to the Gross national income (Suryana, 2013).

Creative industry contributions for Economics according to the ministry RI Trading is:

1. Contributing to domestic products Gross

2. Creating jobs

3. Heightens exports

4. Improve business climate

5. Business Creation

6. Impact on growth of other sectors

7. Impact on social aspects

8. Impact on cultural preservation

Based on the results of industrial mapping Creative Done Department Trade RI, general characteristics of the industry Creatives are as follows:

1. Fluctuations in growth value added Occurs almost in all sub sectors Creative Industries

2. Fluctuations in growth value added followed by fluctuations in the Growing number of companies

3. Fluctuations of absorption growth High labor, but not as tall as Fluctuations in company growth

4. Has technological level and Relatively constant capital productivity.

Creative industries are very responsive to Consumer social phenomena. In contrast, consumers are also very responsive to new goods and services Creative industry created. Creative industries are changing approaches in Industry orientation. If at first is supply Driven industries that respond to the Consumers, being demand driven, namely the Industry-oriented stimulating Consumer demand. Production process Demand driven is not somewhere, rather scattered.

One of the strategies for creating value Popular nowadays is a value innovation strategy From W. Chan Kim and Renee Mauborgne In his book, titled Blue Ocean Strategy. Blue Ocean Strategy is a new area created with Creativity and imagination. In this blue ocean, The company created its own rules, Create your own market and make Competition follows competitors ' standards Become irrelevant anymore. Strategy Blue Ocean is a way of thinking Encouraging to be more creative, creating Added value and are able to create New.

To create value added is required Creativity thinks. Creativity thinks is to generate ideas, ideas, imagination and imaginary-khayanine. The result of creativity Thought it was transformed into a Innovative forms of innovation create value Each chain. Innovation activities that continue to will give birth to the added value that continuously anyway. By innovating To increase the value added, the Product Excellence and Product competitiveness Higher, and the chances are getting bigger. 
To generate added value and power Competitive, every business activity must be in the form Value chain, and each value chain must be Generate value, and then each value is Tembah has novelty, usability and Ease. By increasing Value added, competitiveness and opportunity Company is getting higher. Starting from Provision of inputs, prolction processes, distribution To the goods and services until the to consumers. It is a Process of value sets that can be Generate added value and competitiveness.

The following models are the models that Can be developed to seek opportunities Added value that can be developed to Commercial purposes. Models The added value creation is:

1. Model Creations and ideas There are several different ways to create and Generate Ideas for Increase the value added, namely:

- Creations and ideas develop New Ventures and opportunities (creating The business niches that have not yet Directed).

- Creations and ideas for Developing new products

- Creations and ideas for Develop and Combining inputs.

- Creations and ideas for Develop Capital Resources New.

- Creations and ideas for Develop technology or method or a new way.

- Creations and ideas for Developing the design, size, Quality, packaging, pattern, The privileges of goods and services and Service to be provided.

- Creations and ideas for Developing and expanding channels, distribution agencies, and New Marketing Areas (example: Yomart, Alfamart, Circle K) and To develop agents in Some areas of marketing

- Creations and ideas for Product, through the process of Continuous Improvement/Kaizen Process.

2 Model through production Product development with Emphasis on the following:

- Product-based development Culture with new creations that Diverse (e.g. combining Distinctive products and crafts between Area

- The development of product design Dynamic (the more dynamic the design Product, the higher the value added Economical value of the product).

- The development of product standards According to market share.

- Friendly Product Development User (easy to understand, purchase, Anywhere, anytime by consumers).

- Flexible Product Development and adapt to the needs Consumers and the development Technology.

- The development of quality standards Products

- Introduction of product living environmen (The shorter the Product Life circle , the higher the value of the product).

3. Model through Distribution 140 Creation of value through distribution can Performed as follows:

- The development of cooperation and Partnerships with other parties, whether Government, and private sector, Domestic and foreign.

- The development of networking between industries, Through alliances, both in The provision of raw materials, Production, or in marketing Product results. Use of strategy Business Alliance is meant to Expanding market share and power Product competitiveness.

- Development of marketing areas Dynamic

- Be more active in developing Product Offerings

- The provision of communication tools Appropriate (print media, media Electronics, exhibitions, expositions).

- Development of industrial centers (Silver Industry Centers in Yogyakarta, the shoe industry centers in Ciomas, Bogor).

4. Model through Marketing 
- Market Information development through research or monitoring Consumer needs.

- Monitoring strengths and weaknesses market share.

- Promotion and exhibition development.

- Development of promotional techniques through electronic media y the relevant Dinas

5. Model through innovation

According to Kotler and Keller (2006) there are four ways of innovating innovation:

- By way of invention/revolutionary (Phone discovery by Alexander Graham Bell and aircraft inventions by the Wright brothers).

- With the development (eg McD development by Ray Kroc).

- By duplicating (Duplication of dental treatment by Dentaland).

- With a synthetic way (combining concepts and factors already exist into a new formulation).

6. Creative Entrepreneur Model

7. Models on the job

8. Model Creation Opportunities through supply and demand

This Model can be developed with How to combine Models 1 through model 5, namely with a marketing strategy characteristics-based product results creative industries.

9. Creative economic climate Creation Model

This Model can be developed with way:

Cultural development, especially commercial culture.

- Better development of social attitudes appreciate your own work and others.

- Setting Small Business regulation and Medium.

- Legal protection for small businesses By making it easier patent registration for the product that it created.

- Accelerate economic recognition by patenting bulk Original Products The Indonesian authorities by Authorized.

\section{Past research studies}

The Creative Industry Mapping Studies Department trading 2007 is from the side of the absorption workforce reaching 5.4 million workers with Participation rate of $5.8 \%$. From the export value reached 81.4 trillion rupiah and contribution of $9.13 \%$ to the total national export Value (nominal growth export).

Creative industries are the basis of creative economic development. In Past few years, the role of the creative industry In society has been quite significant. Did UNCTAD (2010) according to UNESCO in Dong \& Haruna (2012) in Zuhdi (2012), Creative industries through culture have become Industry-based economic milestones modern post-industry. Research previously demonstrated industrial influence Creative response to the economic activity community. However, relatively little research has researched the impact of creative industries on national economic activity developing countries, especially Indonesia. Therefore, research is required such as industrial understanding, Better creative and helpful contributing to the growth of the national economy. (Zuhdi, 2012)

Here on Figure 1 economic trend Indonesian creative. From visible graphs that, in line with the slowdown economics in 2015, growth in the creative economy also slowed down, $6.42 \%$ year 2011 and year 2015 only grew $4.5 \%$. After the year 2015, Increased creative economic growth in line with Product growth improved Domestic gross (GDP), But not enough increase share ' creative economy in the economy nationally. 


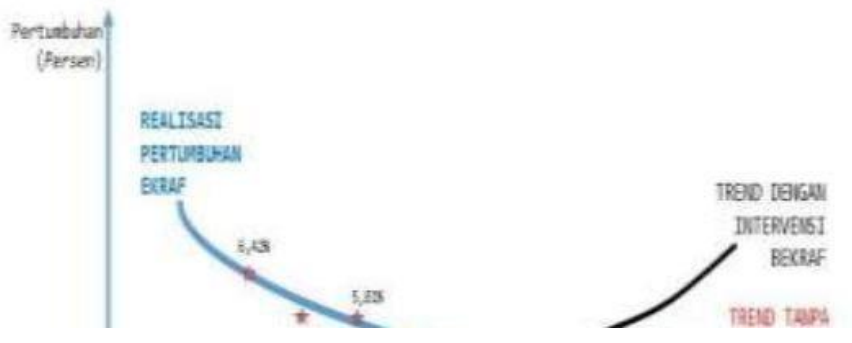

Figure 2. Economic growth Trend Creative Indonesia Source: Bekraf, 2016

A studio from Fahmi (2016) studied appearance and spatial patterns of industrial creativity in a developing country context, Especially Indonesia. His findings show that, in the context of Indonesia, it is important to differentiate between creative industries innovative " and traditional budaya industries ". First category (innovative) describing exploiting New knowledge and wealth intellectual property. The second industry (culture traditional) tends to maintain inheritance values as sales. Indonesia, according to the study, is in fact more important in economic terms than creative industries. Second spatial pattern industry is also different. creative Industries will most likely concentrate on large urban areas, where the innovation and cross-fertilizing ideas may occur. Talent pooling Support and linkages between manufacturers. while, the traditional culture industry is much more slightly dependent on human capital and urbanized economy. Research results indicate that the policy strategy aimed at creative industries can be applied in Indonesia. The area that sufficiently advanced as long as it has capital human and economic diversification can be quite more successful. The area that specializes in the cultural industry traditional strategies can adopt a different to optimize impact. Currently, industrial policy creative does not make this distinction.

From Fahmi's research (2016) be concluded the importance of distinction creative industry categories, particularly in matters of government policy. Policy government will determine the strategy, especially in partnership is required to improve the economy of creative industry sectors. Differ Attendance this category (local wisdom based) be the basis of economic partnership strategy creative. Social and economic settings of regional importance to the industry creative and place based characteristics / this local wisdom creates a condition expected to increase creativity and entrepreneurial behavior (Clare, 2013; Florida, 2002; Lee, Florida, \& Acs, 2004 In Fahmi (2016).

Utama (2015) conducting research on fisherman Lady Kampung Laut. Results research suggests that Empowerment was preceded by women Empowerment Model Planning Fishing village of Kampung Laut which includes starting from the purpose/benefit/form of the program, perpetrators and roles and functions of programmes, program targets, stages, and interconnectedness in a empowerment model. Existence established after the production system went smoothly. The establishment of this cooperative needs supported by the motivation of the consultant. In addition, the implementation program for Empowerment Women will not succeed without The involvement of respected personage, whether formal and informal.

Stages of decision setting continued with the implementation of a program of activities requiring regulatory support from local governments to provide legal certainty. Ongoing 
mentoring during implementation of the program conducted by the government and supported by the consultants are sustainable and cooperation between cooperatives and already formed and BUMD. The potential is high in the profession of entrepreneurship or has a high potential enterpreneur or entrepreneurial candidate. Entrepreneurship training for Women poor in using the model project Based Learning is rated effectively because the majority of successful participants from the level of mastery personality (Soul) entrepreneurship and skills held during the gain real business learning experience.

Agung Utama (2015) conducts research on klaten Regency to measure the potential poor women in developing the local potential-based entrepreneurship wedi Subdistrict, knowing the effectiveness of Project Based Learning models as an entrepreneurial training model In order to empower women poor local potentials in District of Wedi. This research data primary and secondary data. Data analysis techniques using models interactive analysis. Research results show that poor women in District Wedi still live at home that are not habitable, have access to limited education and income low. Poor women in the district wedi have a high potential in entrepreneurial profession or high potential as a candidate for enterpreneur or entrepreneurial. Training entrepreneurship for poor women in wedi Sub-District in order women empowerment and poverty reduction poverty by using models Project Based Learning is rated effectively because the majority of successful participants from the level of mastery personality (Soul) entrepreneurship and skills held during the gain real business learning experience.

\section{Results and discussions}

Currently, the economic driving pattern the world began to shift or change. This shift starts from Industry-based economy being an economy driven by creativity. The economy is based on this creativity is then called the economy creative. As a new driving pattern in Economy based on the Creativity, it is very relevant closely with human resources. Human resources become the base key drivers in the economy Creative. Meanwhile, the resource conditions people in this matter Indonesia in quantity is large and from the relative quality side experienced repair. Predictions made by BKKBN stated that in 2020 to 2030 Indonesia will have a demographic Bonus or can the composition of productive population (working age) is much more than with unproductive populations (age children and old age) and where the when there is a Bonus demography there is a $80 \%$ population composition dominated by women. It is of course opportunities for increased development of Indonesia in various aspects. Women are one of the actors in modern economic development where there is adequate quantity major in Indonesia. Ministry Data MSMES 2012 mentions of the total existing MSMES of 46 million As much as $60 \%$ of the culprit is Women. So it is reasonable that great potential in workforce women should be utilized possible to increase Indonesia's economic growth.

Large numbers of women entrepreneurs are expected to be able to improve economic resilience, as it will be able creating new employment, providing new goods and services with cheaper, and reduces poverty. But outside $60 \%$ of actors the SMES are still many women vulnerable to its economy very low. Their hellessness very reasonable, because of the many factors WHO considers the eye in the women's social stratification levels. The ability of women is still under men so that the opportunity to absorb the production factor also loses far with men. And also women vulnerable to poverty and penetrating action of social stratification, so to thrive is very difficult recall penetration of social stratification one of them comes from the cultural aspects the long-adapted and adopted by the large community. For that required a strategic way to change paradigms of source development More human resources (women) Gender equality.

The truth to be faced is there is a potential amount of comparable between women and Male. But the classic issues are still in the view of development nationally. Low bargaining position 
The potential balance must be eliminated. Because it will actually be very beneficial if it happens Gender equality happens between women and male. If in a household initially men as breadwinners, with gender equality, will occur increased revenue households with women in the productive sectors. Productive sector here can be directed to the sector creative industries. Because of the development of the creative economy that looks at the economy, we need to be aware that theoretical by Trade Department the Republic of Indonesia stated that the creative economy is perfect for applied in Indonesia.

In creative economic literature, many expressed an opinion that a successful creative industry in creating value is determined by the intellectual ability of the capital human capital. Investments in forms of education and training according to your needs, and very important experience in human capital formation. With education will make someone become known, think, behave, act, feel, and be the answer. In accordance with educational purposes that UNESCO expressed that educational objectives directed at: learning to know, learn to be, learn to act and learn to live together (learning to know, learning to be, learning to do, learning to life together).

According to the Schumpeter economic theory, economic development is a source of economic progress, because the history of economic progress is history of human creativity. From the economic development that originated from creativity and self-employed competence Which is reflected in its high economic growth is not will be avoided. It is because of the patterns of individuals who have a model of creativity (creativity capital) that they use to create innovation - innovation so that it has bargaining power high in the economy to theintertwining.

From the explanation can be withdrawn an implementation, the quantity of women is quite large, with the empowerment strategies involving the three main parties or called Triple Helix approach then increased women's bargaining position will be more steady. To form a human being who creative and productive, it takes the collaboration of three main actors, intellectuals (Intellectual), business (Business), and government (Government), as well as Women Creativity then called The Triple Helix plus Environment as Mobilizer the birth of creativity, ideas, and knowledge knowledge, technology and the environment empowerment for growing and economic development in supported by gender equality. When the three actors in The Triple concept Helix symbiotic mutualism with each other, will be created output and the source human resources (women) who have high level of bargaining so that participation in resource utilization power factor production, skill (Skill), technology, knowledge, and strengthening economic and social areas of women. So that later output productivity aggregate will also increase. So with human resource conditions in Indonesia from the great quality, Indonesia ranks fourth in the population. And in quality, using human Development Index Indicator (HDI) released by the UNDP, Indonesian general continues tol experience improvement of the time of your citizenship.

Meanwhile predictions of the experts demographic bonuses in Indonesia in 2020 to 2030 with $80 \%$ domination women must be managed with the well by directing creative industry sectors. It is given that that socio-economic and cultural conditions community that is still setting aside women's role in the aspect of building all fields. This fact can be measured by using the benchmarking Index gender (IPG) showing the majority of women in Indonesia are still limited in the actualisation of self. To achieve positive demographic bonuses (taking advantage of the opportunities demographic bonuses) and upgrades Indonesia's economy later, an absolute female role needs to be optimized and prepared from the beginning. (www.siperubahan.com/read/620/StrategiPemberdayaan-Wanita-Berbasis-EkonomiKreatif\#sth ash.d4hTNHnF.)

In practice, the industry classification Indonesian creative, mainly referring to English Literature (DCMS and John Howkins Model (Ministry of Tourism and creative economy, 2014). 
Definition by the central government interpreted differently throughout the region (based on local wisdom). In some places, such as Bandung, the creative industry considered to include activities that Innovative, while in other cities, regional governments promote old traditionbased activities are embedded in various areas, such as batik traditional crafts, as an industry Creative (Fahmi et al., 2015). It demonstrates, in practice the definition established by the central government not interpreted equally across territories, but local wisdom based on each region.

Based on the study of Libraries and research past has been conducted before, there are a few things that considered in order to form poor Women Empowerment Model:

1. The stages of empowerment preceded by forming models empowerment that is organized Systematic and scientific, with combining theoretical aspects empowerment, needs in field, consultation with related agencies, literature studies, and input from expert empowerment and gender.

2 Cooperative existence after the production system runs smoothly. The establishment of this cooperative needs supported by the giving of motivation from consultants.

3. Program implementation activities for empowerment women will not succeed without involvement of respected personage, both formal and informal.

4. Stages of decision making the above activities are continued with implementation of program activities requiring support regulation of local governments to provide reassurance Law.

5. Ongoing Mentoring during implementation of the program conducted by the government and supported by consultants sustainable cooperation and partnership between cooperatives already formed and BUMD.

6. High potential in living entrepreneurial profession or have a high potential as a candidate for enterpreneur or entrepreneurial.

7. Entrepreneurship Training for Women poor in using the model project Based Learning is rated effectively Because the majority of participants succeed from the level of mastery personality (Soul) entrepreneurship and skills held during the gain a business learning experience real.

The following models are models that can be developed to look for value-added opportunities that can be developed for empowerment women. Value-Added creation Model are:

1. Model Creations and ideas

2. Model through production

3. Model through Distribution

E.g. center development local product industry (e.g. central Silver Handicraft Industry in Yogyakarta, Shoe Industry Center in Ciomas, Bogor).

4. Model through Marketing

5. Model through innovation

6. Creative Entrepreneur Model

7. Models on the job

8. Model Creation Opportunities through Supply and demand

9. Economic climate Creation Model Creative

- Cultural development, especially commercial culture.

- The development of social attitudes appreciates your own work and other people's work.

- Small Business Regulatory arrangements and intermediate.

- Legal protection for business small and easy way registration of patent rights for the products it creates.

- Accelerate economic recognition by parenting bulk Original Products the Indonesian authorities by Authorized. 


\section{Conclusion}

1. Women empowerment is a way to effectively eliminate poverty, hunger, and disease and to support the development sustainable. Perspective implementation gender in seeing poverty not to shrink the meaning poverty suffered by men, but to assert that poverty experienced by women is specific, so it is needed special handling is also

2 The method of women empowerment is to dismantle racial myths, give diverse skills, giving widest opportunities for women to progress and improving various sectors employment, good field of education, Health, economics, social, politics, and culture. It can be done by empowering women-based Creative economy and local Wisdom

3. Empowering Women in development, can be through industry creative based local kearif. Industry creativity is the basis of creative economic development. In recent years, the role of creative industries in the community is quite significant. Research previously demonstrated an influential creative industry towards activities in the economic community. Creative Industries is one of the pillars of building a national economy, because it is able to create resources for human competitiveness in the era of globalization, as well as the welfare of the community, which made it highly regarded strategic. Creative industries are economic development Policy creative. In a few years The role of the creative industry in community is quite significant. Previous studies have shown creative industry influences on community's economic activities.

\section{References}

[1] Dermawan, Abdurraafi' Maududi. (2012). Pemberdayaan Perempuan Melalui Kegiatan Ekonomi Kreatif. Penerbit Raheema Jurnal Studi Gender dan Anak

[2] Fahmi, Fikri Zul, Sierdjan Koster, Jouke van Dijk. 2016. Jurnal. Analyzing the influence of creative industry sector to the national economic structural changes by decomposition analysis: The case of Indonesia. Elsevier Ltd.

[3] Handoko, Waluyo, Sofa Marwat dan Riris Ardhanariswari. (2015). Pembentukan Model Pemberdayaan Perempuan Nelayan di Daerah Tertinggal. Penerbit Universitas Jenderal Soedirman, Purwokerto

[4] Suharto,Edi. (2003). Pembangunan Kebijakan dan Kesejahteraan Sosial. Penerbit Mizan, Bandung

[5] Suryana. 2013. Ekonomi Kreatif: Ekonomi Baru Mengubah Ide dan Menciptakan Peluang. Penerbit Salemba Empat, Jakarta.

[6] Vikaliana, Resista (2016), Pendekatan Kemitraan Model Triple Helix untuk Mengurangi Pengangguran di Kota Bekasi II. Prosiding Seminar Nasional Kemitraan Perguruan Tinggi, Industri dan Pemerintah dalam Meningkatkan Investasi dan Mengurangi Pengangguran di Kota Bekasi, Oktober, Bekasi

[7] Zuhdi, 2012. Jurnal. The location of creative industries in a developing country: The case of IndonesiaElsevier Ltd.JIBES University, Jakarta (Ubaidillah Zuhdi / Procedia Ilmu Sosial dan Perilaku 65 (2012) 980 - 985 981)

[8] Utama, Agung, Titin Hera Widi Handayani. (2015). Model Pemberdayaan Perempuan Miskin Melalui Pelatihan Kewirausahaan Berbasis Potensi Lokal di Kecamatan Wedi Kabupaten Klaten. Penerbit Universitas Negeri Yogyakarta.

[9] Febriyanto, E., Naufal, R. S., \& Utomo, A. P. P. (2020). SISTEM ABSENSI TERINTEGRASI KURIKULUM 13 BERBASIS R+ PADA SDN SUKANAGARA. Technomedia Journal, 4(2), 186-198. 